\title{
Some Factors Influencing the Level of Biosecurity Adoption in Beef Cattle Farms
}

\author{
V. S. Lestari ${ }^{1}$, S. N. Sirajuddin ${ }^{1}$, I. M. Saleh ${ }^{1}$ and K. I. Prahesti ${ }^{1}$ \\ \{veronicasrilestari@unhas.ac, sitti_nurani@yahoo.co.id, ikrarm@yahoo.com, \\ kusumandari.indah@gmail.com \} \\ ${ }^{1}$ Faculty of Animal Husbandry, Hasanuddin University \\ Jl. Perintis Kemerdekaan Km. 10 Makassar 90245, South Sulawesi, Indonesia
}

\begin{abstract}
The purpose of this research was to understand the factors that influence the level of biosecurity adoption in beef cattle farms. This research was conducted in Soppeng Regency, South Sulawesi Province, Indonesia in 2019. The population was beef cattle farmers. The sample was purposively chosen, totaling 30 persons. The data were collected through observation and in-depth interviews using a questionnaire. The questionnaire consisted of 30 questions about biosecurity practices, namely, sanitation, isolation and traffic control. Each question had two possible choices: not adopted was scored 0 and adopted scored 1. A linear regression model was used to assess the factors influencing level of biosecurity adoption. The results showed that the assessed variables, namely age, education, number of family and number of beef cattle explained $86.7 \%$ of the percentage adoption of biosecurity (adjusted $\mathrm{R}^{2}$ ); thus, $13.3 \%$ were influenced by other factors which were not involved in the model. Simultaneously, all variables affected significantly the level of biosecurity adoption $(\mathrm{P}<0.05)$. Partially, education level and herd size affected significantly the level of biosecurity adoption in beef cattle farms ( $\mathrm{P}<0.01$ and $\mathrm{P}<0.05$, respectively). It is suggested that extension and motivation for farmers should be enhanced in order to increase biosecurity adoption.
\end{abstract}

Keywords: Adoption, biosecurity, cattle farms

\section{Introduction}

Demand for meat in Indonesia has increased in relation to population growth and increasing income. However, domestic meat production cannot fulfill the demand for meat; therefore Indonesian Government imports meat and beef cattle from other countries, such as Australia and New Zealand. Low productivity of beef cattle is caused by several factors, such as most beef cattle farmers use semi-intensive or traditional methods to maintain their beef cattle, beef cattle are fed with field grass that lacks nutrition, as well as beef cattle being released in the morning and grounded in the afternoon. This can be a source of disease transmission. 
The Indonesian Government has developed some programs and policies to increase meat production. One of them is biosecurity; for instance, as stated in Government Regulation Republic of Indonesia, No: 47 of 2014 concerning Control and Management of Animal Disease Article 36, the application of biosafety and biosecurity must be carried out at least in nurseries, farms, animal shelters, animal markets ,slaughterhouses, machinery for animal transport, animal health facilities, conservation units and veterinary laboratories[1 ].

According to [1], biosecurity is outlined as a strategic and integrated approach that encompasses the policy and regulative frameworks (including instruments and activities) for analyzing and managing relevant risks to humans, animals and vegetation and health, and associated risks to the atmosphere. Biosecurity has three major components: segregation, improvement and medical aid. Reference [2] add that biosecurity is described as safety from infectious disease, parasite and pest transmission.

General biosecurity measures ought to be enforced in any farm irrespective of any specific downside. Thus, biosecurity, outlined as a group of management practices or measures to forestall introduction and development of pathogens inside and between farms $[4,5]$ has been reported to be more economical thanks to the ability of mass management of diseases in flocks or herds. However, several factors are reported to affect the adoption and proper implementation of biosecurity on farms.

The development of the beef cattle population in Soppeng Regency, Province of South Sulawesi, Indonesia showed a significant increase from 2013 to 2015 (51.65\%). However, the application of biosecurity must be monitored so that cattle are disease-free and the population continues to increase.

To our knowledge, it is rare the research about factors influencing the implementation of biosecurity levels in cattle farmers. This research was intended to determine what factors influence level of biosecurity adoption in beef cattle farmers in Soppeng Regency, Province of South Sulawesi.

\section{Research Methods}

The research has been carried out in Soppeng Regency, South Sulawesi Province in 2019. The population was cattle farmers. The sample was purposively chosen, totalling 30 persons. The information were gathered using a questionnaire through observation and in-depth interviews. Descriptive measures on the farmers and their farms were obtained, and biosecurity adoption was measured from 30 questions on farm consisted of sanitation, isolation and traffic control. Each question was given a rating of 0 for a non-adopted biosecurity measure, and a score of 1 for adopted measures. All the values collected on the farms were summed up (either 0 or 1 per farm). The actions were divided into parts based on biosecurity elements (isolation, traffic control, and hy giene).

For each section, scores were summed to give indexes for each biosecurity aspect. To assess factors affecting the degree adoption of biosecurity in cattle farms, a linear regression model was used. The farmers' associated traits were tested using descriptive statistics (frequency and mean), and incorporated into the model as follows: 


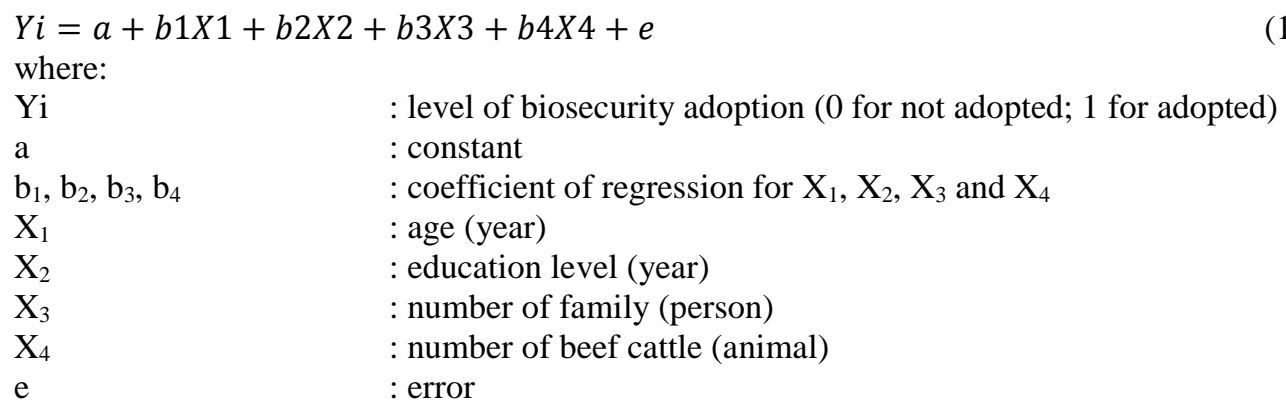

Yi was the variable dependent on it. It was spoken as a total index of biosecurity adoption adopted out of 3 variables (sanitation, traffic control and isolation). The independent variable $\mathrm{X}_{1}$ was expressed as the farmer age (years). The age was supposed to be a negative effect on level of biosecurity adoption. $\mathrm{X}_{2}$ was been conveyed as length of time a farmer had formal education (years). Education was hypothesized to have a positive effect on level of biosecurity adoption. $\mathrm{X}_{3}$ was expressed as number of family members (persons); the family was supposed to have a beneficial impact on level of biosecurity adoption. $\mathrm{X}_{4}$ was expressed as number of beef cattle (animals); the number of beef cattle was assumed to have a positive effect on level of biosecurity. Use of the SPSS variant 23 to estimate the linear regression model and descriptive statistics.

\section{The Results and Discussions}

\subsection{Characteristics of respondents}

Table 1 showed that on average, the age of respondents were in the productive age range (43.56 years old). The median highest level of education of respondents was senior high school $(37.77 \%)$. The median family size of respondents was medium (4-5 members) (53.33\%). Based on number of beef cattle, majority of respondents had less than 10 beef cattle, on average 6.49 animals.

Table 1. Characteristics of Respondents

\begin{tabular}{clc}
\hline Characteristics & Percentage & Mean \\
\hline Age (year) & & \\
$\bullet \quad 17-28$ & 4.44 & 43.56 \\
$\bullet \quad 29-40$ & 35.56 & \\
$\bullet \quad 41-52$ & 33.33 & \\
$\bullet \quad 53-65$ & 26.67 & \\
Level of Education & & \\
- Elementary School & 35.56 & \\
- Junior High School & 26.67 &
\end{tabular}


- Senior High School

Number of family (person)

- $1-3$

- 4-5

- 6-7

Number of beef cattle/herd size (animal)

- $<10$

- $10-20$

- $>20$
37.77

33.33

53.33

13.33

6.49

\subsection{Factors affecting level of biosecurity adoption}

As shown in Table 2, the determination coefficient adjusted $\mathrm{R}^{2}$ was 0.867 , which indicated that $86.7 \%$ of the general variance level of four independent variables included in the model could explain the adoption index of biosecurity measures, while $13.3 \%$ other factors not included in the model have been affected.

Table 2. Regression Analysis

\begin{tabular}{lll}
\hline Characteristics & Regression Coefficient & $P$ value \\
\hline Age $\left(\mathrm{X}_{1}\right)$ & 0.058 & $0.538^{\text {ns }}$ \\
Education level $\left(\mathrm{X}_{2}\right)$ & 0.950 & $0.009^{* *}$ \\
Number of family $\left(\mathrm{X}_{3}\right)$ & 1.744 & $0.048^{*}$ \\
Herd size $\left(\mathrm{X}_{4}\right)$ & 0.042 & $0.863^{\text {ns }}$ \\
\hline
\end{tabular}

*significant $(\mathrm{P}<0.05) \quad * *$ significant $(\mathrm{P}<0.01) \quad$ ns $=$ not significant

$\mathrm{R}^{2}=0.867 \quad \mathrm{R}=0.934 \quad \mathrm{~F}=69.330 \quad \mathrm{P}=0.00$

The model can be expressed as:

$Y=0.058 X_{1}+0.950 X_{2}+1.744 X_{3}+0.042 X_{4}+e$

As shown in Table 2, simultaneously (F statistics), all variables significantly influenced the level of biosecurity adoption $(\mathrm{P}<0.01)$. All the coefficients are anticipated signs except for the age of respondents. Education has affected the implementation of innovation, according to [ 6 ]. The low educational level affected the breeders ' being slow or quick in technology develop ment as it enabled reduced catchment capacity comparedto greater educational rates. This finding was in accord with that of [3], who found that biosecurity results were associated with herd size considerably $(\mathrm{P}<0.05)$ and producers' education level $(\mathrm{P}<0.01)$.

Significant and wide associations existed between the socioeconomic features of the manufacturersandcertain methods of biosecurity. Reference [4] discovered farm size has been impacted by the implementation by farmers of uncooked milk protection policies. Reference [5] noted that older human beings had more difficulties adopting innovations. Those who adopted improved breeds in preference to indigenous people and organisations benefiting from 
animal husbandry support policies have a tendency to adopt improvements more in advance than others, to a statistically significant level.

The results of this research in opposite that of [6], who observed that farmer's age, gender, amount of training, and herd size did not have an effect on the extent of biosecurity on pig farms. Reference [7] argued that farm earnings, the predominant aspects affecting the implementation of biosecurity on laying hen farms were family size and social capital $(\mathrm{P}<0.05)$.

According to [8], Finnish farmers have been satisfied with their biosecurity on-farm. Although the biosecurity phase was not specifically high, 80 percent of farmers say they were pleased with their policies. Furthermore, the application of biosafety measures could be enhanced. Despite the fact that the today in Finland, the disease scenario is perfect, one must be ready for threatening disease epidemics.

Reference [9] stated that adoption of biosecurity measures were impacted by training, off-farm income, animal health education and other farmers living in the region. Increasing distance from the extension station and a farmer residing in Omusati location, on the other hand, has precipitated a decline in farm animal technologies. The more the farmer knows the better the farm animal techniques are adopted. Training allows people to recognize the significance and advantages of adopting new technology, and give them an extra willingness to undertake and observe new improvements in their farms.

\section{Conclusions}

Simultaneously, age, education, family size and herd size influenced significantly the level of biosecurity adoption $(\mathrm{P}<0.01)$. In part, education and herd size affected the level of biosecurity adoption $(\mathrm{P}<0.01$ or $\mathrm{P}<0.05$, respectively). The model generated including all independent variables explained $86.7 \%$ of the response, while $13.3 \%$ was unexplained, due to variables not included in the model.

\section{Acknowledgement}

A big appreciation and many thanks to Hasanuddin University who provide funding for doing this research

\section{References}

[1] D. Manzella and J. Vapnek, "Development of an analytical tool to assess Biosecurity legislation," Dev. an Anal. Tool to Assess Natl. Biosecurity Legis., no. 96, 2007.

[2] G. E. Valergakis, G. Arsenos, and G. Oikonomou, "Biosecurity measures on cattle farms," J. Hell. Vet. Med. Soc., vol. 59, no. 1, pp. 9-22, 2008.

[3] M. F. Can and N. Altuğ, "Socioeconomic implications of biosecurity practices in smallscale dairy farms," Vet. Q., vol. 34, no. 2, pp. 67-73, 2014.

[4] X. YANG, K. Z. Chen, and X. KONG, "Factors affecting the adoption of on-farm milk 
safety measures in Northern China-An examination from the perspective of farm size and production type," J. Integr. Agric., vol. 18, no. 2, pp. 471-481, 2019.

[5] A. Aksoy, M. Külekçi, and F. Yavuz, "Analysis of the factors affecting the adoption of innovations in dairy farms in Erzurum Province, Turkey," African J. Agric. Res., vol. 6, no. 13, pp. 2966-2970, 2011.

[6] M. K. Kouam and J. O. Moussala, "Assessment of factors influencing the implementation of biosecurity measures on pig farms in the Western Highlands of Cameroon (Central Africa)," Vet. Med. Int., vol. 2018, 2018.

[7] V. S. Lestari et al., "Factors influencing biosecurity adoption on laying hen farmers," $J$. Indones. Trop. Anim. Agric., vol. 37, no. 4, pp. 302-307, 2012.

[8] L. Sahlström, T. Virtanen, J. Kyyrö, and T. Lyytikäinen, "Biosecurity on Finnish cattle, pig and sheep farms-results from a questionnaire," Prev. Vet. Med., vol. 117, no. 1, pp. 59-67, 2014.

[9] E. C. Musaba, "Analysis of factors influencing adoption of cattle management technologies by communal farmers in Northern Namibia," Livest. Res. Rural Dev., vol. 22, no. 6 , p. 104, 2010.

[1] The Directorate General of Livestock. : Government Regulation of the Republic of Indonesia Number 47. Ministry of Agriculture, Jakarta (2014)

[4] Gunn G. J., Heffernan C., Hall M., McLeod A., Hovi M. Measuring and comparing constraints to improved biosecurity amongst GB farmers, veterinarians and the auxiliary industries. Preventive Veterinary Medicine. 2008;84(3-4):310-323 (2008)

[5] Fasina F. O., Lazarus D. D., Spencer B. T., Makinde A. A., Bastos A. D. S.: Cost implications of African Swine Fever in smallholder Farrow-to-Finish Units: Economic benefits of disease prevention through biosecurity. Transboundary and Emerging Diseases. ;59(3):244-255 (2012)

[6] Soekartawi. Prinsip Dasar Komunikasi Pertanian. Universitas Indonesia Press, Jakarta (1988) 